\title{
Complex cytogenetic findings in the bone marrow of a chronic idiopathic myelofibrosis patient
}

\author{
Kronik idiopatik myelofibrozis olgusunun kemik iliğinde kompleks sitogenetik \\ bulgular
}

\author{
Tuğçe Bulakbaşı Balcıํ, Meltem Yüksel2 , Zerrin Yılmaz¹, Feride iffet Şahin'1 \\ ${ }_{1}^{1}$ Department of Medical Genetics, Baskent University Faculty of Medicine, Ankara, Turkey \\ ${ }^{2}$ Dr. Abdurrahman Yurtaslan Ankara Oncology Training and Research Hospital, Ankara, Turkey
}

\begin{abstract}
Chronic idiopathic myelofibrosis is a myeloproliferative disorder characterized by splenomegaly, myeloid metaplasia and reactive bone marrow fibrosis. Karyotype analysis of the bone marrow is an integral part of the diagnosis, especially as a discriminative tool in ruling out reactive conditions. The frequency of clonal cytogenetic anomalies in this disease is the highest among its group, varying between 30 and 75\%. Among these, trisomy 1q, 20q-, 13q- and +8 are the most common aberrations. Here we report a 66-year-old male patient whose bone marrow biopsy revealed signs of chronic myeloproliferative changes and dysmegakaryopoiesis. He was administered hydroxyurea treatment, splenic radiotherapy and multiple transfusions. The patient worsened in the following months and the second bone marrow biopsy revealed myelofibrosis. Cytogenetic analysis of this bone marrow sample revealed a complex karyotype reported to be $46, \mathrm{XY}$, del( $(9)$ (q22q34),t(8;17;21)(q22;q21;q22)[23]/46,XY[2], with a previously undefined three-way translocation and deletion in chromosome 9. The patient died shortly thereafter. (Turk J Hematol 2010; 27: 113-6)
\end{abstract}

Key words: Chronic idiopathic myelofibrosis, cytogenetics

Received: August 15, 2008 Accepted: April 8, 2009

\section{Özet}

Kronik idiopatik myelofibrozis, kronik myeloproliferatif hastalıklardandır ve splenomegali, myeloid metaplazi ve reaktif kemik iliği fibrozisi ile karakterizedir. Bu hastalıkların tanısında, özellikle de reaktif durumları ekarte etmek için kemik iliğinden kromozom analizi oldukça önemli bir araçtır. İdiopatik myelofibrozis, bu grup içerisinde en yüksek klonal sitogenetik anomali sıklığına sahiptir (\%30-75). Trizomi 1q, 20q-, 13q- ve +8 en sık gözlenen anomalilerdendir. Bu yazımızda masif splenomegali ile başvuran 66 yaşında erkek olgunun bulguları sunulmaktadır. Olgunun kemik iliği biyopsisinde kronik myeloproliferatif değişiklikler ve dismegakaryopoez saptandı. Hidroksiüre tedavisi, splenik radyoterapi ve çok sayıda transfüzyon alan hastanın kliniği ilerleyen aylarda kötüleşti. Yapılan ikinci kemik iliği biyopsisisinde myelofibrozis gözlendi. Bu örneğin sitogenetik incelemesi sonucu daha önce tanımlanmamış üç yollu bir translokasyon ve 9. kromozomda delesyon saptandı. Karyotipi 46,XY,del(9)(q22q34),t(8;17;21)(q22;q21;q22)[23]/46,XY[2] olarak belirlendi. Olgu kısa süre sonra kaybedildi. (Turk J Hematol 2010; 27: 113-6)

Anahtar kelimeler: Kronik idiopatik myelofibrozis, sitogenetik 


\section{Introduction}

Chronic myeloproliferative disorders (CMPDs) are a group of heterogeneous clonal stem cell disorders that can be defined by specific cytomorphological phenotypes and sometimes genetic features [1]. The frequency of clonal cytogenetic anomalies is variable in these disorders. Chronic idiopathic myelofibrosis (CIMF) is characterized by splenomegaly, myeloid metaplasia and reactive bone marrow fibrosis, and it has the highest karyotype aberration rate [1-3]. Approximately 50\% of patients diagnosed with CIMF harbor cytogenetic anomalies, and among these, trisomy 1q, 20q-, 13q- and +8 are the most common aberrations [3-5]. Abnormalities of chromosomes 5, $6,7,9$ and 12 have also been reported. If leukemic transformation occurs, clonal evolution to a more complex karyotype is common [1]. Thus, cytogenetic analysis is a valuable tool in CIMF, both at diagnosis to distinguish from secondary myelofibrosis and chronic myeloid leukemia $(\mathrm{CML})$ and during the follow-up [1].

Here we report a CIMF case with multiple complex cytogenetic abnormalities and poor outcome to emphasize the significance of cytogenetic studies in patients with this disease.

\section{Case Report}

A 66-year-old male patient with congestive heart failure was referred to the hematology clinic because of low hemoglobin levels and thrombocytosis. He had dyspnea and fatigue and on physical examination had massive splenomegaly (spleen size $20 \mathrm{~cm}$ on abdominal ultrasound). The leukocyte count was $10.900 / \mathrm{mm}^{3}$, hemoglobin was $9.8 \mathrm{~g} / \mathrm{dl}$ and platelet count was $1.699 .000 / \mathrm{mm}^{3}$. The first bone marrow biopsy, which was performed in April 2004, revealed signs of chronic myeloproliferative changes and dysmegakaryopoiesis. He received hydroxyurea treatment $(20 \mathrm{mg} / \mathrm{kg} /$ day $)$ and transfusion support for two years. The splenomegaly regressed with therapy, and then reappeared, when the patient had a poorer clinical status and needed weekly transfusions, in November 2006. The leukocyte count at that time was $9.000 / \mathrm{mm}^{3}$, hemoglobin was $8.8 \mathrm{~g} / \mathrm{dl}$ and platelet count was $469.000 / \mathrm{mm}^{3}$. A second bone marrow biopsy was performed and showed myelofibrosis. Despite the hydroxyurea therapy, his spleen was enlarging and there was progressive decrease in hemoglobin and platelet counts. Palliative radiotherapy was started in February 2007 when his leukocyte count was $11.800 / \mathrm{mm}^{3}$, hemoglobin $7.6 \mathrm{~g} / \mathrm{dl}$ and platelet count $25.000 / \mathrm{mm}^{3}$. At the end of radiotherapy, his spleen had been reduced to almost normal volume and the patient became transfusion-independent. He was re-admitted to the hospital in October 2007 due to fatigue, palpitation and left upper abdominal pain. On physical examination, he had massive splenomegaly; his leukocyte count was $3.200 / \mathrm{mm}^{3}$, hemoglobin $7.4 \mathrm{~g} / \mathrm{dl}$ and platelets $354.000 / \mathrm{mm}^{3}$. A new bone marrow biopsy was performed to rule out leukemia. The results were compatible with the earlier diagnosis of myelofibrosis. Dexamethasone therapy was initiated and thalidomide therapy was planned. His bone marrow sample was sent to our laboratory for cytogenetic studies. Fluorescence in situ hybridization (FISH) with LSI BCR-ABL ES Dual Color Translocation Probe (Vysis, USA) was performed. Fusion signal was detected, though below the cut-off value of our laboratory, and was thus reported as negative. After routine cultures were set up using Bone Marrow Karyotyping Medium (Biological Industries, Israel) and Hematopoietic Cell Karyotyping Medium (Biological Industries, Israel), G-banding of chromosomes revealed a complex karyotype, including rearrangements in chromosomes 8, 9, 17 and 21. Following

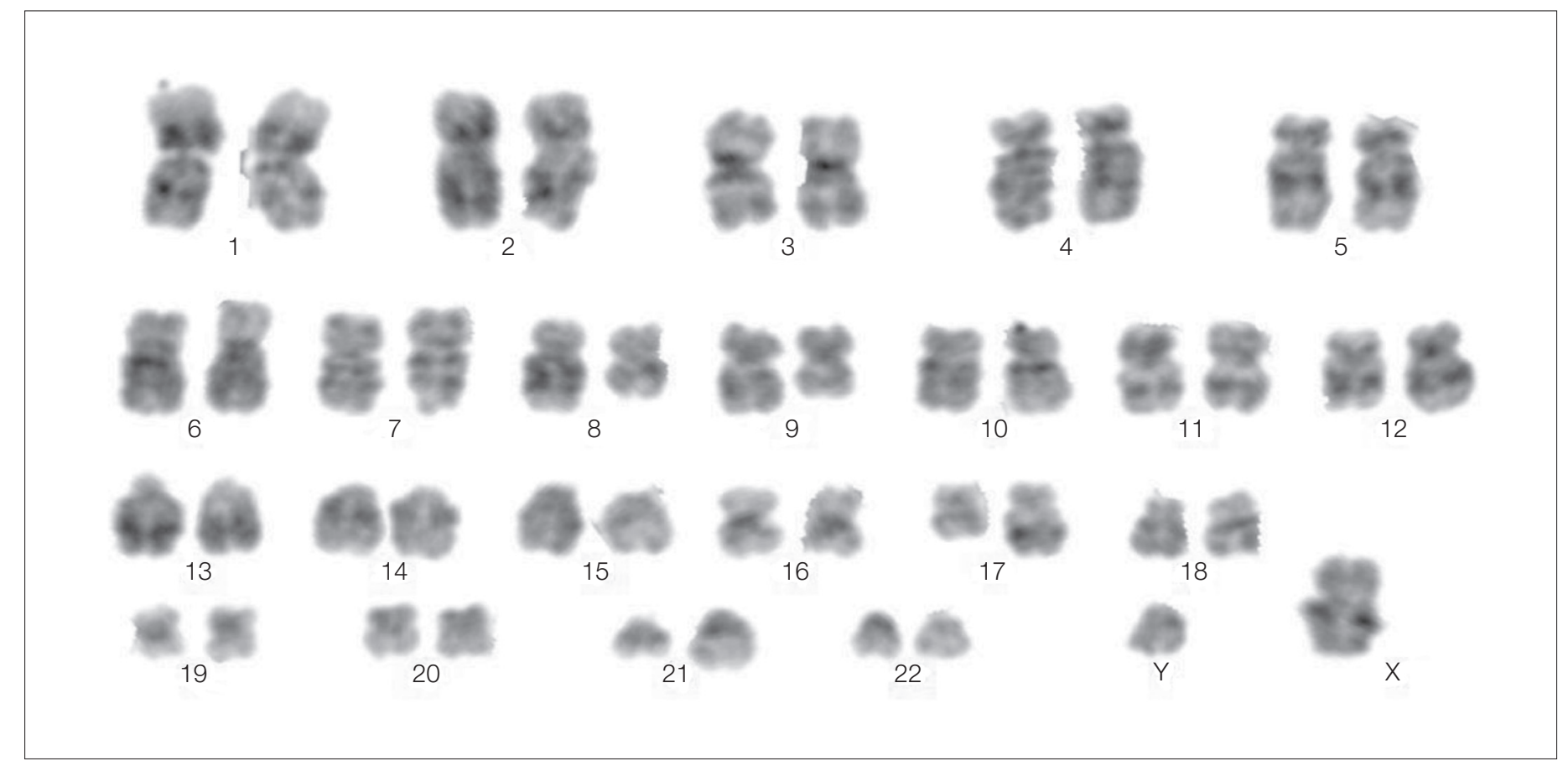

Figure 1. Karyotype of the patient: 46,XY,del(9)(q22q34),t(8;17;21)(q22;q21;q22) 
analysis of 25 metaphases, the karyotype was designated according to ISCN 2005 and reported as: 46,XY,del(9) (q22q34),t(8;17;21)(q22;q21;q22)[23]/46,XY[2] (Figure 1). To define the rearrangements, FISH was performed with Whole Chromosome Paint probes 8, 9, 17 and 21 (Vysis, USA) on selected metaphases (Figures 2, 3). Based on the results, an interstitial deletion was found in chromosome 9 and a threeway translocation was verified between chromosomes 8, 17 and 21. Written informed consent was obtained from the patient. The patient died shortly after his bone marrow aspirate was sampled.

\section{Discussion}

Karyotype analysis of the bone marrow is an integral part of the diagnosis in myeloid disorders, and in recent years, it has gained more importance in the diagnosis of CMPDs, especially as a discriminative tool in ruling out reactive conditions [5]. In CMPD patients, cytogenetic analysis is not the primary test as a diagnostic tool. The first-line diagnostic tools are clinical and hematological parameters. Both conventional cytogenetics and FISH are performed as the second-line tests. Chromosome banding visualizes the complete karyotype of the patients. FISH analyses can be used to detect suspected or known chromosome aberrations [1].

It may be difficult to obtain a representative sample from patients with CIMF because the bone marrow is fibrotic in this disease and the cells that are obtained have low proliferative capacity in vitro $[4,6]$. Thus, the overall frequency of cytogenetic abnormalities may not be determined with certainty. The reported frequencies range between 30 to $75 \%$ [4]. As mentioned above, the most common cytogenetic aberrations

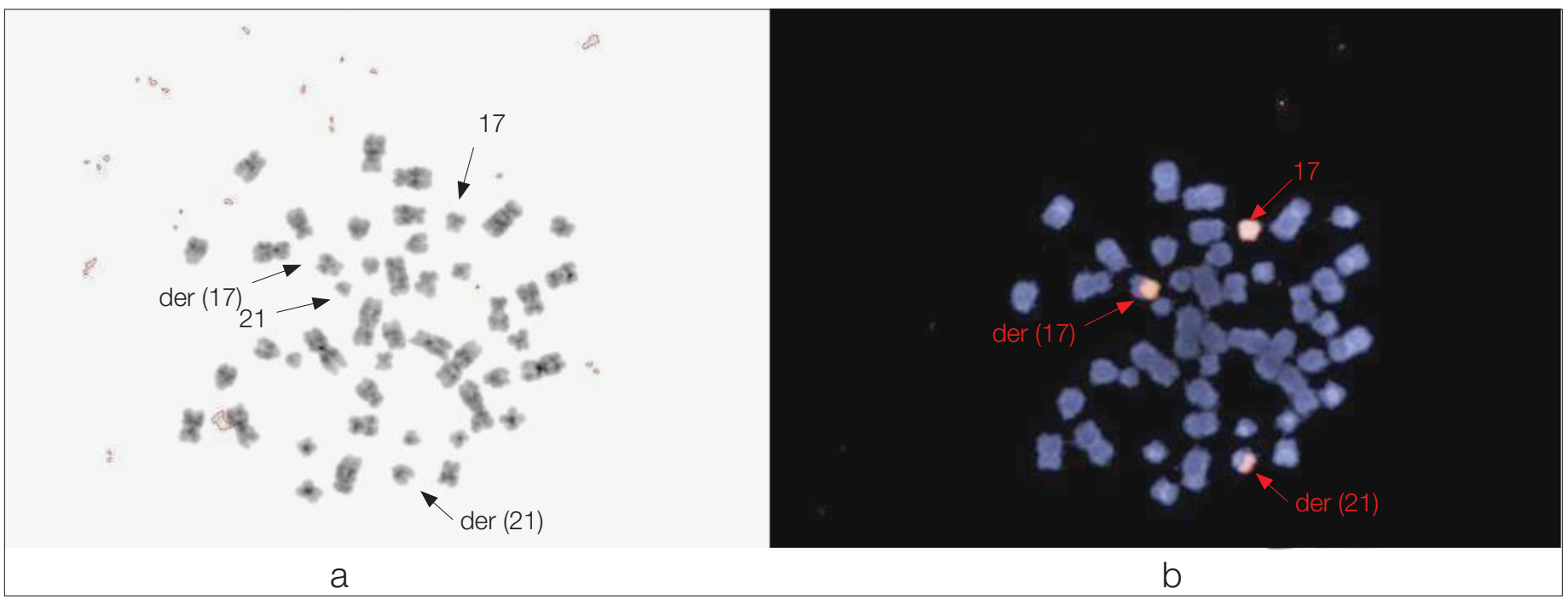

Figure 2. a: Metaphase spread of the patient; relevant chromosomes are marked with arrows

b: The same metaphase after fluorescence in situ hybridization with Whole Chromosome Probe 8 Spectrum Orange (Vysis, USA); relevant chromosomes are marked with arrows

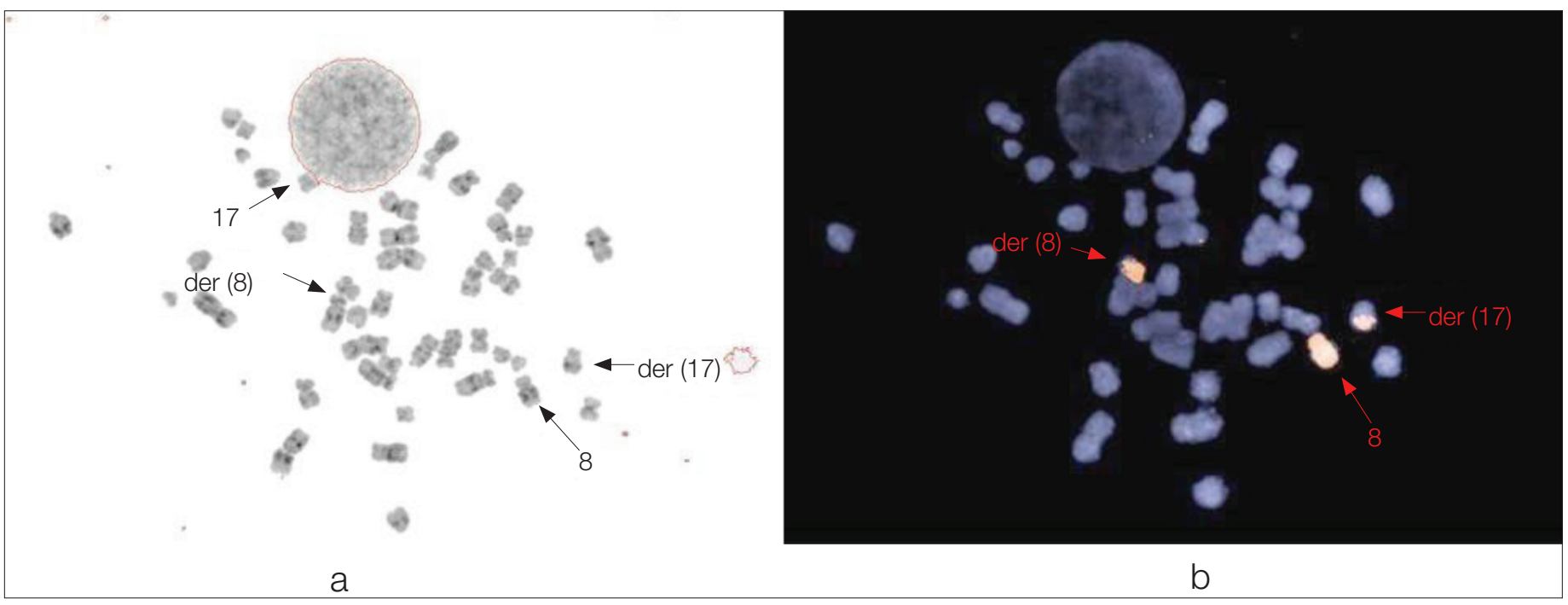

Figure 3. a: Metaphase spread of the patient; relevant chromosomes are marked with arrows

b: The same metaphase after fluorescence in situ hybridization with Whole Chromosome Probe 17 Spectrum Orange (Vysis, USA); relevant chromosomes are marked with arrows 
found in CIMF include $+8,20 q^{-}, 13 q^{-},+1 q,+9$ and +21 . There is no specific aberration, and unlike myeloid leukemias, balanced translocations are rare $[2,4]$. Some of these anomalies (involving chromosomes 1, 5, 7, 9) are almost always associated with additional changes, and thus are suspected to be a result of genetic instability, while others (20q-, 13q-, +8) appear as sole anomalies and are thought to be pathogenetically relevant [5]. Of these, $13 q$ - and $20 q$ - are considered as favorable abnormalities while all other abnormalities are regarded as unfavorable, but the findings are not consistent in all series $[5,6]$.

Regarding the current patient, the three-way translocation together with the deletion in the long arm of chromosome 9, resulting in such a complex karyotype, could have contributed unfavorably to the prognosis and could be associated with the progression of the disease.

On the other hand, the fact that the patient received radiotherapy along with hydroxyurea treatment may raise the question of chromosome breaks due to radiation and myelotoxic drugs. Hydroxyurea treatment has not yet been associated with a significant increase in myeloblastic transformation in myeloproliferative disorders, but its myelotoxic effects could have contributed to the worsening hematological status and myelofibrosis in this patient $[7,8]$.

Splenic irradiation is considered as a local palliative therapy to reduce the spleen size in elderly patients with CMPDs. The fact that CIMF is mostly seen in the older patient population, in whom surgical treatment would bring about higher rates of mortality and morbidity, has led clinicians to use this nonsurgical alternative in this group of patients. Complex karyotypic rearrangements in CIMF have not been reported to appear as a result of radiotherapy. However, the most expected lifethreatening complication of splenic irradiation is myelosuppression, and the potential outcome of this therapy has not yet been fully optimized for CIMF patients [9].

It has been known for many years that radiation exposure could cause single or double strand breaks in the chromosomes, leading to dicentric chromosomes, translocations and more complex rearrangements $[10,11]$. The hematological effect of radiotherapy has also been studied, and along with chemotherapy, it is known to cause different kinds of neoplasms $[11,12]$. Therefore, there is a theoretical possibility that the three-way complex translocation and the deletion in our patient may have been caused by the therapy he received during the course of his disease. Our patient worsened about eight months after receiving radiotherapy. Unfortunately, we do not have information about the cytogenetic status of the bone marrow in this patient before therapy, so it is not possible to decide whether the complex karyotype had been present from the beginning, or whether it was due to disease progression or to the radio- and/or chemotherapy.
It is obvious that cytogenetic analysis of bone marrow is the first-line analysis in both determining the diagnosis and foreseeing the prognosis in myeloid disorders.

\section{Conflict of interest}

No author of this paper has a conflict of interest, including specific financial interests, relationships, and/or affiliations relevant to the subject matter or materials included in this manuscript.

\section{References}

1. Haferlach T, Bacher U, Kern W, Schnittger S, Haferlach C. The diagnosis of $\mathrm{BCR} / \mathrm{ABL}$-negative chronic myeloproliferative diseases (CMPD): a comprehensive approach based on morphology, cytogenetics, and molecular markers. Ann Hematol 2008;87:1-10.

2. Demory JL, Dupriez B, Fenaux P, Laï JL, Beuscart R, Jouet JP, Deminatti M, Bauters F. Cytogenetic studies and their prognostic significance in agnogenic myeloid metaplasia: a report on 47 cases. Blood 1988;72:855-9.

3. Ahmed A, Chang CC. Chronic idiopathic myelofibrosis: clinicopathologic features, pathogenesis, and prognosis. Arch Pathol Lab Med 2006;130:1133-43.

4. Djordjevic V, Dencic-Fekete M, Jovanovic J, Bizic S, Jankovic G, Bogdanovic A, Cemerikic-Martinovic V, Gotic M. Cytogenetics of agnogenic myeloid metaplasia: a study of 61 patients. Cancer Genet Cytogenet 2007; 173:57-62.

5. Tefferi A, Mesa RA, Schroeder G, Hanson CA, Li CY, Dewald GW. Cytogenetic findings and their clinical relevance in myelofibrosis with myeloid metaplasia. Br J Haematol 2001;113:763-71.

6. Strasser-Weippl K, Steurer M, Kees M, Augustin F, Tzankov A, Dirnhofer S, Fiegl M, Simonitsch-Klupp I, Gisslinger H, Zojer N, Ludwig $\mathrm{H}$. Prognostic relevance of cytogenetics determined by fluorescent in situ hybridization in patients having myelofibrosis with myeloid metaplasia. Cancer 2006;107:2801-6.

7. Nand S, Stock W, Godwin J, Fisher SG. Leukemogenic risk of hydroxyurea therapy in polycythemia vera, essential thrombocythemia, and myeloid metaplasia with myelofibrosis. Am J Hematol 1996;52:42-6.

8. Burkitt MJ, Raafat A. Nitric oxide generation from hydroxyurea: significance and implications for leukemogenesis in the management of myeloproliferative disorders. Blood 2006;107:2219-22.

9. McFarland JT, Kuzma C, Millard FE, Johnstone PA. Palliative irradiation of the spleen. Am J Clin Oncol 2003;26:178-83.

10. Tucker JD. Low-dose ionizing radiation and chromosome translocations: a review of the major considerations for human biological dosimetry. Mutat Res 2008;659:211-20.

11. Cornforth MN. Perspectives on the formation of radiation-induced exchange aberrations. DNA Repair (Amst) 2006;5:1182-91.

12. Leone G, Pagano L, Ben-Yehuda D, Voso MT. Therapy-related leukemia and myelodysplasia: susceptibility and incidence. Haematologica 2007;92:1389-98. 